\title{
IDENTIFIKASI KEDALAMAN AKUIFER DAERAH TEMPAT PEMBUANGAN AKHIR (TPA) ANTANG MAKASSAR MENGGUNAKAN METODE GEOLISTRIK KONFIGURASI WENNER
}

\author{
* Abdul Mun'im \\ Jurusan Teknik Lingkungan, \\ Fakultas Teknik Stitek \\ Nusindo Makassar \\ abdu.thq@gmail.com
}

Sappewali

Jurusan Teknik Lingkungan,

Fakultas Teknik

Stitek Nusindo Makassar

Sappe1291@gmail.com

Ayusari Wahyuni

Jurusan Fisika,

Fakultas Saintek,

UIN Alauddin Makassar

Ayusari_wahyuni@uinalauddin.ac.id

* koresponden author
Abstrak - Penelitian mengenai identifikasi kedalaman akuifer daerah Tempat Pembuangan Akhir (TPA) sangat berguna untuk mengetahui sebaran potensi akuifer dangkal yang dapat dimanfaatkan oleh warga yang bermukim sekitar TPA Antang secara mudah dan efisien. Metode penelitian menggunakan pengukuran geolistrik konfigurasi wenner dan interpretasi penampang 2D resistivitas bawah permukaan untuk mengetahui kedalaman akuifer daerah pemukiman sekitar TPA Antang. Berdasarkan variasi nilai resistivitas dalam penampang 2D dapat diketahui pada lokasi penelitian kedalaman lapisan yang mengandung akuifer terdapat pada kedalaman 2- 6 meter yang berpotensi sebagai akuifer dangkal yang tergolong sebagai akuifer bebas. Kata Kunci : Akuifer, geolistrik, konfigurasi wenner.

Abstract - Research on the identification of the depth of the aquifer in the final disposal site (TPA) is very useful to determine the potential distribution of shallow aquifers that can be exploited by residents who live around TPA Antang easily and efficiently. The research method uses geoelectric measurements of the Wenner configuration and interpretation of $2 D$ subsurface resistivity to determine the depth of the aquifer in the residential area around the TPA Antang. Based on the variation of the resistivity value in the $2 D$ cross section, it can be seen at the research location that the depth of the layer containing aquifers is at a depth of 2-6 meters which is potential as a shallow aquifer which is classified as a free aquifer.

Keywords : Aquefer,geoeletric, wenner configuration. 


\section{A. PENDAhULUAN}

Kota Makassar adalah ibu kota propinsi Sulawesi Selatan yang memiliki luas areal 175,79 $\mathrm{km}^{2}$ yang terdiri dari 14 kecamatan. Kecamatan Manggala yang merupakan lokasi Tempat Pembuangan Akhir (TPA) Antang adalah salah satu dari kecamatan yang ada di kota Makassar (Umum, 2011). Jumlah penduduk yang berada di sekitaran TPA antang semakin bertambah, sehingga kebutuhan akan air bersih di sekitar TPA juga sangat penting bagi kebutuhan warga di lokasi tersebut. Permasalahan yang saat ini dialami adalah kurangnya cadangan air bersih di sekitar TPA Antang (Rachmat and Pamungkas, 2014). Sehingga diperlukannya tindakan praktis untuk dapat mengidentifikasi adanya sumber air bersih di bawah permukaan wilayah sekitar TPA Antang.

Tempat Pembuangan Akhir (TPA) umumnya menggunakan sistem pembuangan terbuka, sampah-sampah dibiarkan menumpuk dan tanpa pengolahan sampah yang mengakibatkan meningkatnya limbah lindi (air sampah) sehingga dapat mempengaruhi kualitas air tanah di sekitar area TPA (Yatim and Mukhlis, 2013); (Rahmi and Edison, 2019). Pencemaran air adalah pencemaran badan air (seperti lautan, laut, danau, sungai, air tanah dan lainnya) yang biasanya disebabkan oleh aktivitas manusia. Perubahan dalam sifat fisik, kimia atau biologis air akan memiliki konsekuensi yang merugikan bagi organisme hidup. Pencemaran air mengakibatkan krisis air tawar, mengancam sumber-sumber air minum dan kebutuhan penting lainnya bagi manusia dan makhluk hidup lain (Alkhair, 2013). Identifikasi adanya resapan limbah yang mengganggu air tanah dapat dilakukan dengan melihat litologi batuan bawah permukaan (Maria Christine Sutandi, 2012). Air tanah tersimpan dalam lapisan akuifer yang berada di bawah permukaan tanah yang dapat dideteksi dengan menggunakan metode geofisika (Wijaya and Resistivitas, 2015); (Rabeh et al., 2018). Akuifer ini umumnya merupakan hasil rombakan batuan, berukuran halus sampai kasar, terdiri dari pasir lempungan pasir, kerikil dan kerakal (Asrafil, Botjing and Rugayya, 2019).

Salah satu metode geofisika dalam menentukan informasi bawah permukaan adalah metode geolistrik (Pratiwi, Susanti and Dewi, 2018); (Muntaha, Latifah and Sastrawan, 2019). Metode ini menggunakan menggunakan prinsip dasar teori kelistrikan dalam pencarian sumber air tanah (W.M.Telford, 1990). Konsep dasar dari Metoda Geolistrik adalah Hukum Ohm yang pertama kali dicetuskan oleh George Simon Ohm. Beda potensial yang timbul di ujung-ujung suatu medium berbanding lurus dengan arus listrik (Rahmaniah; Ayusari wahyuni, 2020). Metode geolistrik terdiri beberapa konfigurasi dalam pengambilan data, namun dalam penelitian ini fokus menggunakan konfigurasi wenner dalam penentuan kedalaman akuifer dangkal di sekitar TPA Antang. Konfigurasi wenner adalah metode pengambilan data dengan cara mengetahui sifat aliran listrik di bawah permukaan dengan mengukur di atas permukaan tanah (Yu, Sasamoto and Iwata, 2019). 


\section{B. METODE}

Penelitian ini dilakukan di lokasi daerah pemukiman sekitar wilayah Tempat Pembuangan Akhir (TPA) Antang dengan menggunakan konfigurasi wenner. Lokasi penelitian ditunjukan pada Gambar 1.

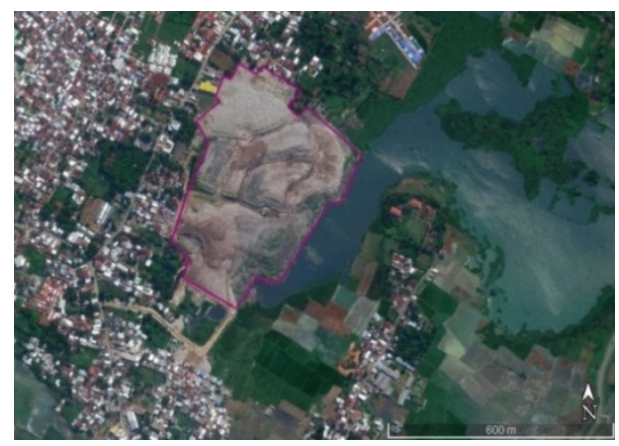

Gambar 1. Lokasi Penelitian.

Tahapan awal dalam dalam penelitian ini adalah studi pustaka untuk mengetahui kondisi geologi daerah penelitian yang dapat memberikan gambaran awal tentang kondisi bawah permukaan daerah penelitian. Hasil studi geologi digunakan untuk membantu dalam tahap interpretasi penampang 2D resistivitas bawah permukaan. Peta geologi lokasi penelitian terlihat pada Gambar 2. Lokasi penelitian berada pada satuan formasi Qac memiliki warna biru muda pada Gambar 2, dimana masih terdapat rawa rawa di sekitar lokasi penelitian. Adapun Satuan formasi berupa endapan aluvium, rawa dan pantai (Qac ): kerikil. pasir, lempung, lumpur dan batugamping koral.Terbentuk dalam lingkungan sungai, rawa, pantai dan delta. Pada lokasi penelitian terlihat 6 titik pengambilan data sampel air sumur dan 3 lokasi pengambilan data geolistrik.

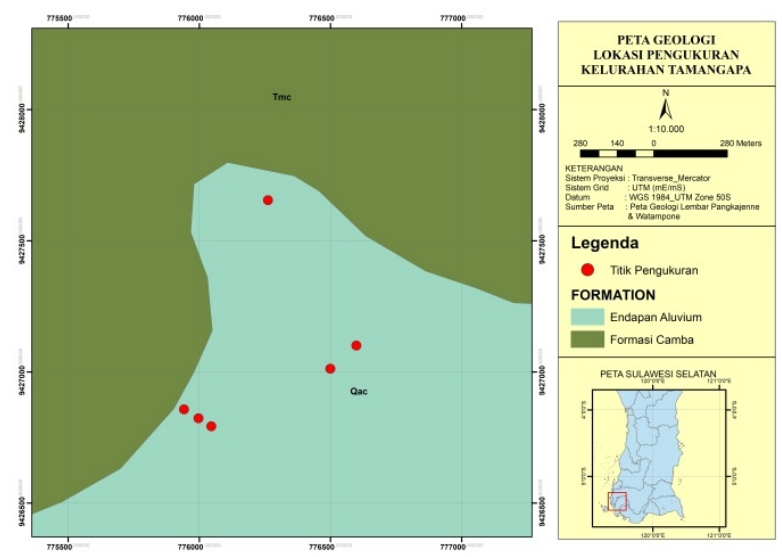

Gambar 2. Peta lokasi penelitian

Tahapan kedua adalah melakukan pengukuran geolistrik konfigurasi wenner pada 3 lintasan pengukuran yang dilakukan pada hari sabtu 12 September 2020 di kecamatan Manggala. Panjang bentangan pada penelitian ini sejauh 145 meter dengan arah lintasan Timur Laut - Barat Daya. Alat 
yang digunakan adalah geolistrik multichanel seperti yang terlihat pada Gambar 3 dan susunan konfigurasi wenner sesuai dengan Gambar 4. Analisis data menggunakan software Res2dinv untuk menggambarkan penampang 2D hasil pengukuran.

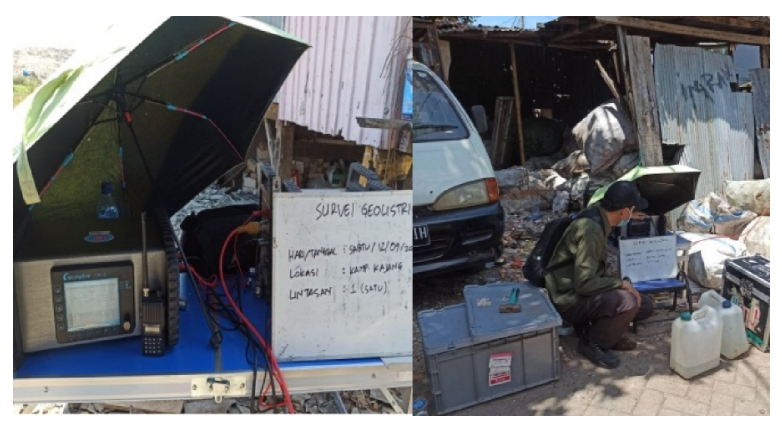

Gambar 3. Geolistrik Multichanel (a); Proses Pengambilan data (b).

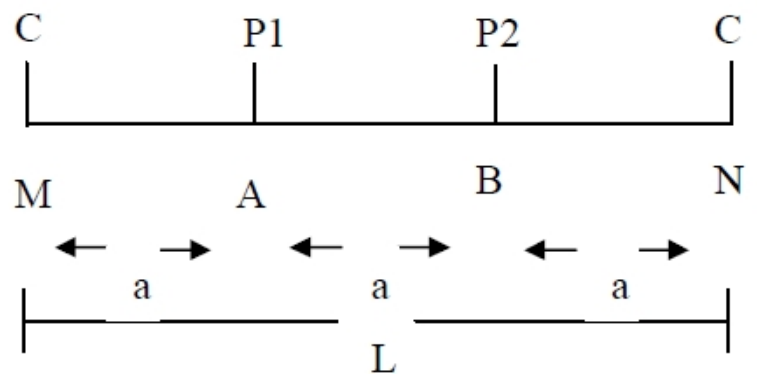

Gambar 4. Elektroda arus dan potensial pada konfigurasi Wenner (Sastrawan and Latifan, 2019).

\section{HASIL DAN PEMBAHASAN}

Pada penelitian ini diperoleh raw data dari pengukuran geolistrik resistivity konfigurasi wenner dengan jumlah elektroda 30 buah dan jumlah datum 135 data. Pengukuran dilakukan pada untuk pada lokasi yang berbeda yakni kampung Kajang, Borong Jambu dan Bontoa dengan 3 lintasan pengukuran dengan spasi 5 meter.

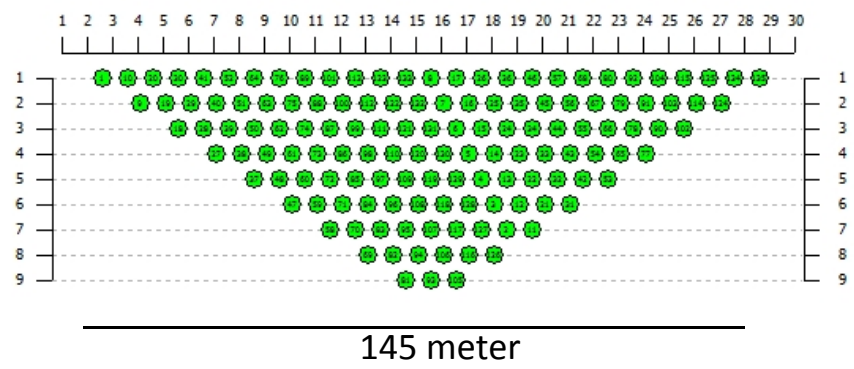

Gambar 5. Datum Elektroda 


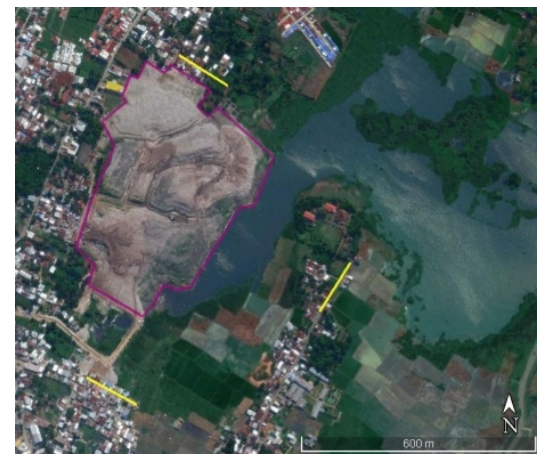

Gambar 6. Titik pengukuran data geolistrik

\section{a. Lintasan 1 (Kampung Kajang)}

Lintasan ini berada di kampung Kajang, sekitar daerah pemukiman TPA Antang. Berdasarkan hasil pengolahan data lapangan menghasilkan penampang yang memiliki rentang nilai resistivitas $2,42-126,24 \Omega m$.

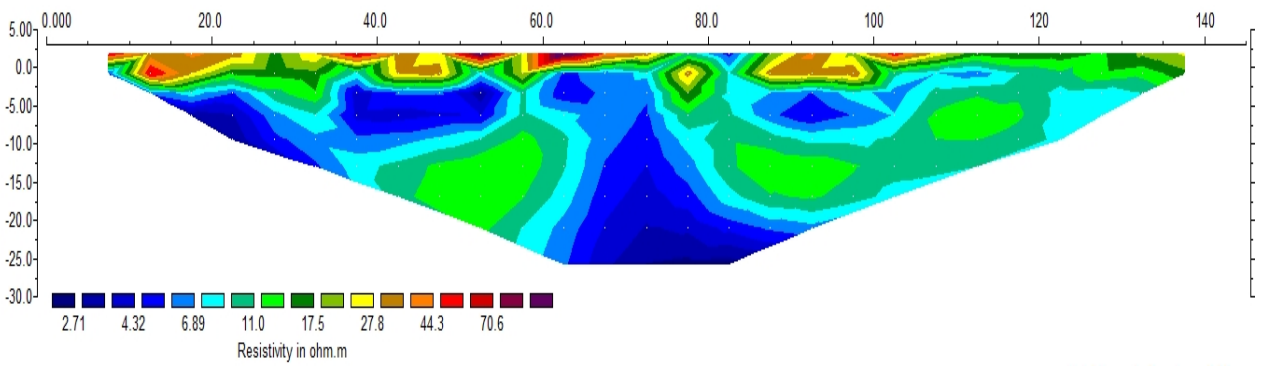

Gambar 7. Hasil pengukuran lintasan 1.

Lintasan pengukuran merupakan daerah reklamasi danau yang kontak langsung dengan TPA. Dari penampang resistivitas diperoleh 2 lapisan berdasarkan nilai resistivitas yang telah diikat dengan informasi kondisi tanah dan litologinya. Lapisan pertama dengan nilai resistivitas 27,8 - 126,24 $\Omega \mathrm{m}$ dengan ketebalan berkisar 2-5 meter di bawah permukaan (original ground surface), merupakan sedimen hasil penimbunan didominasi oleh sedimen silty sand sampai ke pasir (sand) berdasarkan informasi pengamatan di lapangan. Lapisan kedua dengan nilai resistivitas 2,42-27,8 $\Omega$ m dengan kedalaman bervariasi mulai dari 2-5 meter dari permukaan. Nilai resisitvitas yang sangat kecil menunjukkan lapisan ini merupakan sedimen yang tidak kompak sehingga ruang pori yang ada di antara butirnya terjenuhkan oleh air. Lapisan ini diidentifikasi sebagai lapissan akuifer dangkal.

\section{b. Lintasan 2 (Borong Jambu)}

Dari penampang resistivitas diperoleh 2 lapisan berdasarkan nilai resistivitas yang telah diikat dengan informasi litologinya.

Lapisan pertama dengan nilai resistivitas 13,3 - 38,4 $\Omega \mathrm{m}$ dengan kedalaman bervariasi mulai dari 1,25 - 30 meter dari permukaan. Lapisan ini merupakan sedimen rawa, dominan pasir mulai dari pasir sampai dengan silty sand (pasir berlanau). Nilai resisitvitas yang sangat kecil menunjukkan lapisan ini 
merupakan sedimen yang tidak kompak sehingga ruang pori yang ada di antara butirnya terjenuhkan oleh air. Lapisan ini diidentifikasi sebagai lapisan akuifer dangkal.

Lapisan kedua dengan nilai resistivitas 38,4-56,2 $\Omega \mathrm{m}$ dengan ketebalan berkisar 5 meter di bawah permukaan (original ground surface) pada ujung utara dari lintasan, merupakan sedimen hasil penimbunan didominasi oleh sedimen silty sand sampai ke lanau (silt) berdasarkan informasi pengamatan di lapangan.

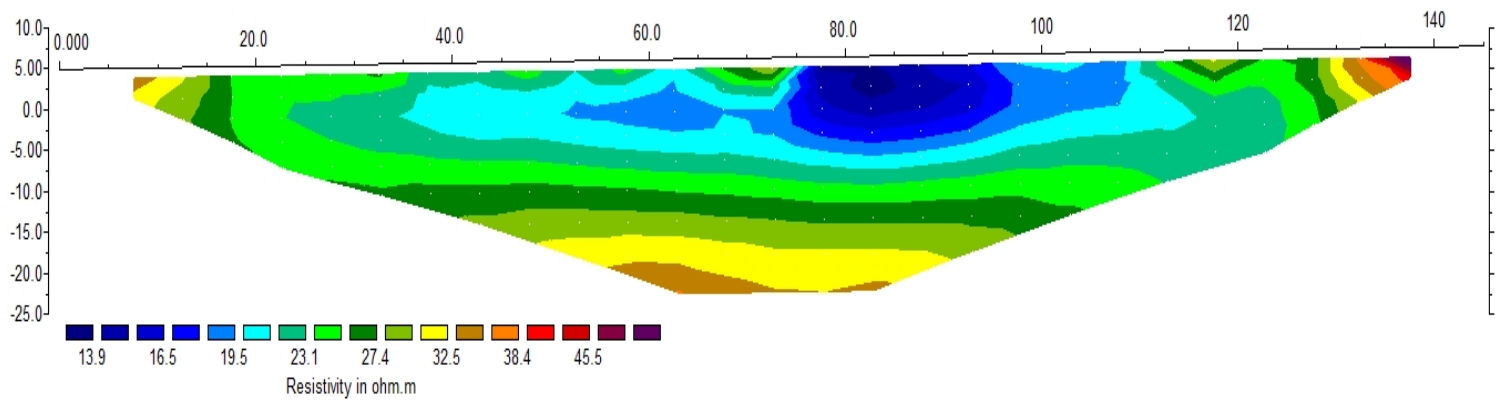

Gambar 8. Hasil pengukuran lintasan 2.

\section{c. Lintasan 3 (Bontoa)}

Dari penampang resistivitas diperoleh 2 lapisan berdasarkan nilai resistivitas yang telah diikat dengan informasi litologinya. Lapisan pertama dengan nilai resistivitas 11,5 - 33,64 $\Omega \mathrm{m}$ dengan ketebalan berkisar 2-6 meter di bawah permukaan (original ground surface), merupakan sedimen hasil penimbunan didominasi oleh sedimen silty sand sampai ke pasir (sand) berdasarkan informasi pengamatan di lapangan.

Lapisan kedua dengan nilai resistivitas 3,02 - 11,5 $\Omega \mathrm{m}$ dengan kedalaman bervariasi mulai dari 2 - 6 meter dari permukaan. Lapisan ini merupakan sedimen rawa, dominan pasir mulai dari pasir sampai dengan silty sand (pasir berlanau). Nilai resisitvitas yang sangat kecil menunjukkan lapisan ini merupakan sedimen yang tidak kompak sehingga ruang pori yang ada di antara butirnya terjenuhkan oleh air. Lapisan ini diidentifikasi sebagai lapisan akuifer dangkal. Berdasarkan nilai resistivitasnya, fluida yang mengisi lapisan ini dibagi atas dua jenis fluida dengan nilai resistivitas rendah 3,02 - 5,71 $\Omega \mathrm{m}$ diduga pengaruh dari lindi yang bersifat elektrolit sehingga mudah mengalirkan arus listrik, dan fluida dengan nilai resistivitas 5,71 - 11,5 $\Omega \mathrm{m}$ merupakan fluida yang belum terkontaminasi lindi.

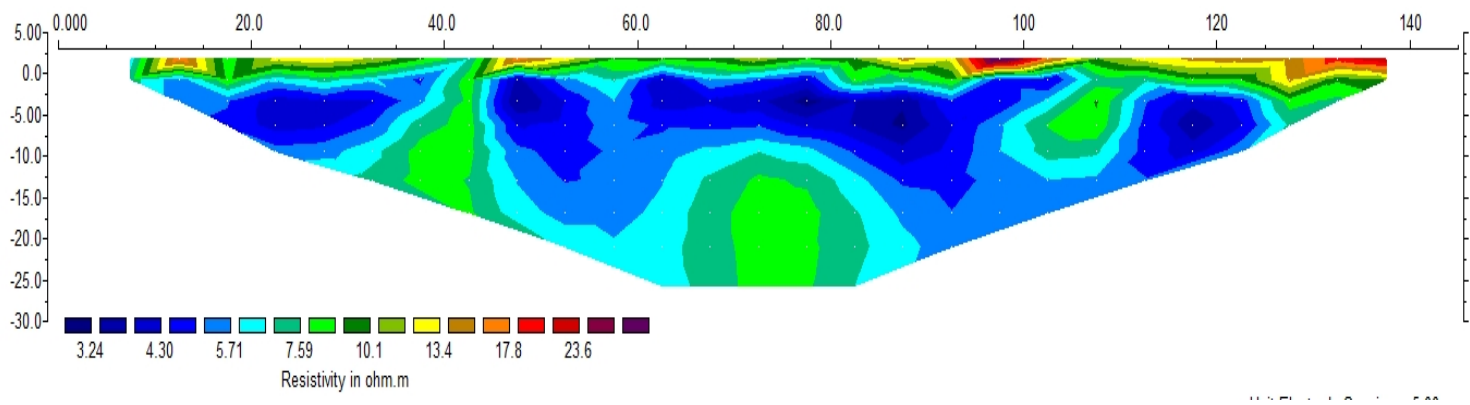

Gambar 9. Hasil pengukuran lintasan 3. 


\section{SIMPULAN}

Pada penelitian ini diidentifikasi sebagai lapissan akuifer dangkal. Berdasarkan nilai resistivitasnya, fluida yang mengisi lapisan ini dibagi atas dua jenis fluida dengan nilai resistivitas rendah 3,02 - 5,71 $\Omega \mathrm{m}$ diduga pengaruh dari lindi yang bersifat elektrolit sehingga mudah mengalirkan arus listrik, dan fluida dengan nilai resistivitas 5,71 - 11,5 $\Omega \mathrm{m}$ merupakan fluida yang belum terkontaminasi lindi.

\section{DAFTAR RUJUKAN}

Alkhair, A.pratiwi (2013) 'Pencemaran Air', Jurnal Pencemaran Air.

Asrafil, A., Botjing, M. U. and Rugayya, S. (2019) 'Pendugaan Lapisan Akuifer Menggunakan Metode Geolistrik dengan Teknik Vertical Electrical Sounding (VES) di Lokasi TPA Sampah Desa Jononunu, Parigi, Sulawesi Tengah', Natural Science: Journal of Science and Technology, 8(1), pp. 68-76. doi: 10.22487/25411969.2019.v8.i1.12638.

Maria Christine Sutandi (2012) ‘Air Tanah’, Fakultas Teknik Jurusan Teknik Sipil Universitas Kristen Maranatha Bandung.

Muntaha, M., Latifah, J. A. and Sastrawan, F. D. (2019) 'Identifikasi Struktur Tanah Bawah Permukaan dan Kedalaman Akuifer Daerah Tempat Pemrosesan Akhir (TPA) Manggar Menggunakan Metode Resistivitas Konfigurasi Schlumberger', Jurnal Aplikasi Teknik Sipil, 17(1), p. 1. doi: 10.12962/j2579-891x.v17i1.3836.

Pratiwi, D. P., Susanti, N. and Dewi, I. K. (2018) 'Penerapan Metode Geolistrik Konfigurasi Wenner Mapping untuk Mengetahui Rembesan Air Lindi di TPA Talang Gulo Jambi', JoP, ISSN $2502-2016,4(1)$, pp. 18-22.

Rabeh, T. et al. (2018) 'Exploration and evaluation of potential groundwater aquifers and subsurface structures at Beni Suef area in southern Egypt', Journal of African Earth Sciences. Elsevier Ltd. doi: 10.1016/j.jafrearsci.2018.11.025.

Rachmat, A. R. and Pamungkas, A. (2014) 'Faktor-Faktor Kerentanan yang Berpengaruh terhadap Bencana Banjir di Kecamatan Manggala Kota Makassar', Jurnal Teknik ITS, 3(2), pp. C178C183. Available at: http://ejurnal.its.ac.id/index.php/teknik/article/view/7263\%0Ahttp://ejurnal.its.ac.id.

Rahmaniah; Ayusari wahyuni (2020) 'Survey on potential of geothermal in Lompobattang Mountains South Sulawesi by resistivity method Survey on potential of geothermal in Lompobattang Mountains South Sulawesi by resistivity method'. doi: 10.1088/1755-1315/575/1/012160.

Rahmi, A. and Edison, B. (2019) 'Identifikasi Pengaruh Air Lindi (Leachate) Terhadap Kualitas Air Di Sekitar Tempat Pembuangan Akhir (Tpa) Tanjung Belit’, jurnal APTEK, 11(1), pp. 1-6.

Sastrawan, F. D. and Latifan, J. A. (2019) 'Estimasi Kedalaman Akuifer Dangkal Daerah TPA Manggar dengan Menggunakan Metode Geolistrik Konfigurasi Wenner’, 5(2), pp. 131-136.

Umum, I. K. (2011) ‘Sulawesi Selatan', pp. 547-560.

W.M.Telford (1990) W. M. Telford, L. P. Geldart, R. E. Sheriff - Applied Geophysics (1990, Cambridge University Press) - libgen.lc.pdf.

Wijaya, A. S. and Resistivitas, A. M. G. (2015) 'Aplikasi Metode Geolistrik Resistivitas Konfigurasi Wenner Untuk Menentukan Struktur Tanah di Halaman Belakang SCC ITS Surabaya’, XIX, pp. $1-5$.

Yatim, E. M. and Mukhlis, M. (2013) 'Pengaruh Lindi ( Leachate) Sampah Terhadap Air Sumur 
Penduduk Sekitar Tempat Pembuangan Akhir ( Tpa ) Air Dingin', Jurnal Kesehatan Masyarakat Andalas, 7(2), pp. 54-59.

Yu, J., Sasamoto, A. and Iwata, M. (2019) 'Wenner method of impedance measurement for health evaluation of reinforced concrete structures', Construction and Building Materials. Elsevier Ltd, 197, pp. 576-586. doi: 10.1016/j.conbuildmat.2018.11.121. 